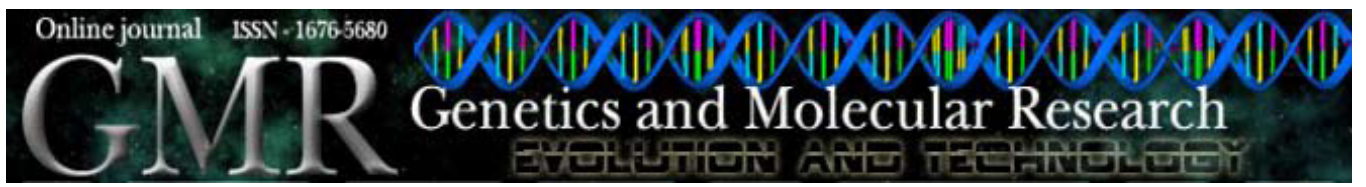

\title{
Imprinted gene expression in in vivo- and in vitro-produced bovine embryos and chorio-allantoic membranes
}

\author{
F. Perecin ${ }^{1,2}$, S.C. Méo ${ }^{3}$, W. Yamazaki ${ }^{1}$, C.R. Ferreira ${ }^{2}$, G.K.F. Merighe ${ }^{2}$, \\ F.V. Meirelles ${ }^{2 *}$ and J.M. Garcia ${ }^{1 *}$ \\ ${ }^{1}$ Departamento de Medicina Veterinária Preventiva e Reprodução Animal, \\ Faculdade de Ciências Agrárias e Veterinárias, Universidade Estadual \\ Paulista, Jaboticabal, SP, Brasil \\ ${ }^{2}$ Departamento de Ciências Básicas, Faculdade de Zootecnia e \\ Engenharia de Alimentos, Universidade de São Paulo, Pirassununga, SP, Brasil \\ ${ }^{3}$ Embrapa Pecuária Sudeste, São Carlos, SP, Brasil \\ *These authors contributed equally to this study. \\ Corresponding author: F. Perecin \\ E-mail: fperecin@fcav.unesp.br
}

Genet. Mol. Res. 8 (1): 76-85 (2009)

Received October 29, 2008

Accepted November 20 ,2008

Published January 27, 2009

\begin{abstract}
Cloning by nuclear transfer is often associated with poor results due to abnormal nuclear reprogramming of somatic donor cells and altered gene expression patterns. We investigated the expression patterns of imprinted genes $I G F 2$ and $I G F 2 R$ in 33to 36-day bovine embryos and chorio-allantoic membranes derived from in vivo- and in vitro-produced embryos by somatic cell nuclear transfer (SCNT), parthenogenetic activation, and in vitro fertilization (IVF). There was a lower IGF2 expression rate in the SCNT (0.19) and parthenogenetic $(0.02)$ groups when compared to in vivo and IVF embryos $(2.01 ; \mathrm{P}<0.05)$. In the chorio-allantoic membranes, IGF2 showed a baseline expression pattern $(\mathrm{P}<0.05)$ in parthenotes (0.001) when compared to in vivo, IVF (3.13), and SCNT (0.98) groups. IGF2R was less expressed $(\mathrm{P}<0.05)$ in SCNT chorio-allantoic membranes $(0.25)$ when compared to the in vivo group. The low expression of $I G F 2$ in parthenogenetic embryos and
\end{abstract}


chorio-allantoic membranes confirms its imprinted status in cattle. Alterations in the relative frequency of $I G F 2$ and $I G F 2 R$ transcripts were observed in SCNT-derived bovine embryos and chorioallantoic membranes, respectively, supporting the hypothesis that abnormalities in the expression of imprinted genes are causes of the low efficiency of SCNT procedures in this species.

Key words: Cattle; Epigenetics; Genomic imprinting; IGF2; IGF2R; Nuclear transfer

\section{INTRODUCTION}

The limited success of somatic cell nuclear transfer (SCNT) is often related to incorrect nuclear reprogramming of donor cells. There were two epigenetic mechanisms underlying this process: DNA methylation and histone remodeling. Both are involved in the control of several cellular processes, such as the control of gene expression, $\mathrm{X}$ inactivation, and genomic imprinting (Li et al., 1993; Holmes and Soloway, 2006).

Genomic imprinting can be defined as the unequal contribution of parental genomes during development. Imprinted genes play important roles in the development of the fetus and placenta, and some alterations associated with reproductive technologies are believed to be caused by failures in imprinted gene regulation. However, despite the large use of these biotechniques in cattle, there are few studies focusing on these genes in cattle.

The present study was designed to compare the relative frequency of messenger RNA (mRNA) of the imprinted genes IGF2 (paternally expressed) and IGF2R (maternally expressed) in bovine embryos and chorio-allantoic membranes obtained in vivo or by in vitro fertilization (IVF), SCNT, and parthenogenesis.

\section{MATERIAL AND METHODS}

\section{Chemicals}

Chemicals and media were purchased from Sigma Chemical Co. (St. Louis, MO, USA), unless otherwise stated.

\section{In vivo embryo production}

Embryos on days 33 to 36 of development and chorio-allantoic membranes from in vivo-produced embryos were obtained after superovulation and artificial insemination of cycling Bos taurus x B. indicus crossbreed cows. Follicular waves were synchronized by dominant follicle aspiration and insertion of a progesterone (P4) releasing device (Crestar, Intervet Internation $\mathrm{GmbH}$, Unterschleissheim, Germany). Two hundred milligrams FSH (Folltropin $^{\mathrm{TM}}$, Bioniche Animal Health, Belleville, Canada) was administered im in eight decreasing doses, twice a day, for four consecutive days (40 mg x 2; $30 \mathrm{mg} \times 2 ; 20 \mathrm{mg} \times 2$, and $10 \mathrm{mg}$ $\mathrm{x} 2$ ), beginning 3 to 4 days after follicular aspiration. To induce luteolysis, along with the fifth FSH injection, a dose of $150 \mu \mathrm{g}$ prostaglandin F2 $\alpha$ analogue (D-cloprostenol; Preloban, 
Intervet International $\mathrm{GmbH}$ ) was administered $\mathrm{im}$. Removal of the P4 releasing device was performed together with the sixth FSH injection. Finally, $0.1 \mathrm{mg}$ gonadotrophin-releasing hormone (GnRH; Fertagyl, Intervet Internation $\mathrm{GmbH})$ was administered $i m$ along with the eighth FSH injection in order to induce LH surge. Cows were inseminated 12 and 24 h postGnRH application with Nelore (Bos indicus) sire semen.

\section{In vitro embryo production}

Abattoir-derived ovaries from crossbreed cows were transported to the laboratory in saline solution at $28-32^{\circ} \mathrm{C}$. Follicles ( 3 to $8 \mathrm{~mm}$ ) were aspirated using an $18-\mathrm{G}$ needle attached to a $20-\mathrm{mL}$ syringe. Oocytes with at least four layers of cumulus cells (COCs) and homogeneous cytoplasm were selected for in vitro maturation. Groups of 20 to 25 oocytes were matured under mineral oil (Dow Corning Co., Midland, MI, USA) in droplets $(100 \mu \mathrm{L})$ of tissue culture medium (TCM-199, Gibco BRL, Grand Island, NY, USA) supplemented with 10\% $(\mathrm{v} / \mathrm{v})$ heat-inactivated $\left(55^{\circ} \mathrm{C}\right.$ for $\left.30 \mathrm{~min}\right)$ fetal bovine serum (FBS), $1.0 \mu \mathrm{g} / \mathrm{mL}$ FSH (Folltropin $^{\mathrm{TM}}$ ), $50 \mu \mathrm{g} / \mathrm{mL}$ hCG (Profasi ${ }^{\mathrm{TM}}$, Serono, São Paulo, Brazil), $1.0 \mu \mathrm{g} / \mathrm{mL}$ estradiol, $0.20 \mathrm{mM}$ sodium pyruvate, and $83.4 \mu \mathrm{g} / \mathrm{mL}$ amikacin (Instituto Biochimico, Rio de Janeiro, Brazil). Oocytes were maintained in an atmosphere of $5 \% \mathrm{CO}_{2}$ in air at $38.5^{\circ} \mathrm{C}$ for $24 \mathrm{~h}$.

\section{In vitro fertilization}

To produce embryos by IVF, at $24 \mathrm{~h}$ post-maturation, expanded COCs were transferred to $100 \mu \mathrm{L}$ drops of TALP-IVF medium supplemented with $6 \mathrm{mg} / \mathrm{mL}$ bovine serum albumin (BSA), $30 \mu \mathrm{g} / \mathrm{mL}$ heparin, $18 \mu \mathrm{M}$ penicillamine, $10 \mu \mathrm{M}$ hypotaurine, $1.8 \mu \mathrm{M}$ epinephrine, and $0.2 \mathrm{mM}$ sodium pyruvate. Semen from a Nelore bull was used, and motile spermatozoa were separated by density gradient in 45 and $90 \%$ (v/v) Percoll. Final sperm concentration used was $1 \times 10^{5}$ live spermatozoa per drop. Oocytes and sperm cells were co-incubated for $22 \mathrm{~h}$ at $38.5^{\circ} \mathrm{C}$ under $5 \% \mathrm{CO}_{2}$ in air and maximum humidity. At the end of co-culture, presumptive zygotes were washed in TALP-IVF medium and transferred to embryo culture medium.

\section{Somatic cell nuclear transfer}

The somatic cell line used as nucleus donor was derived from a skin biopsy obtained from a 19-year-old Nelore cow (Bos indicus). The biopsy was cut into small pieces ( $3 \mathrm{~mm}$ ) and the explants were cultured in 25- $\mathrm{mm}^{2}$ flasks containing Dulbecco's modified Eagle's medium (DMEM; Gibco BRL) supplemented with 50\% (v/v) FBS and $83.4 \mu \mathrm{g} / \mathrm{mL}$ amikacin at $38.5^{\circ} \mathrm{C}$ under an atmosphere of $5 \% \mathrm{CO}_{2}$ in air and maximum humidity. This medium was used during the first 3 days of culture for primary cell line establishment. Cell culture was then maintained using DMEM plus $10 \%$ (v/v) FBS and $83.4 \mu \mathrm{g} / \mathrm{mL}$ amikacin. When primary cell line confluence was achieved, cells were treated with $0.05 \%(\mathrm{w} / \mathrm{v})$ trypsin supplemented with $1 \%(\mathrm{v} / \mathrm{v})$ poultry serum and replated. All passages were cultured until confluence. Cells from early passages were frozen in DMEM supplemented with $10 \%$ (v/v) dimethyl sulfoxide (Merck \& Co. Inc., Whitehouse Station, NJ, USA) and stored in liquid nitrogen. Thawed cells, cultured for 3 to 4 passages, were used in nuclear transfer procedures as nucleus donors.

At $18 \mathrm{~h}$ post-maturation, expanded COCs were placed in $0.2 \%(\mathrm{w} / \mathrm{v})$ hyaluronidase 
for $5 \mathrm{~min}$ and gentle pipetting was performed to remove the cumulus cells. Oocytes showing the first polar body were selected and incubated in synthetic oviductal fluid (SOF) with $10 \mu \mathrm{g} /$ $\mathrm{mL}$ Hoechst 33342 stain and $7.5 \mu \mathrm{g} / \mathrm{mL}$ cytochalasin B at $38.5^{\circ} \mathrm{C}$ under $5 \% \mathrm{CO}_{2}$ in air and maximum humidity. Enucleation was performed in HEPES-buffered SOF (HSOF; Wells et al., 1999) supplemented with $10 \%$ (v/v) FBS and $7.5 \mu \mathrm{g} / \mathrm{mL}$ cytochalasin $\mathrm{B}$, with a $25-\mu \mathrm{m}$ (external diameter) glass pipette, by removing the first polar body and the surrounding cytoplasm. Enucleation was confirmed by visualizing the aspirated chromatin inside the pipette under ultraviolet light. After enucleation, cytoplasts were washed twice in HSOF $+10 \%(\mathrm{v} / \mathrm{v})$ FBS and held in this medium until reconstruction. Individual fibroblast cells were transferred into the perivitelline space of each recipient oocyte in HSOF containing $10 \%(\mathrm{v} / \mathrm{v})$ FBS and $7.5 \mu \mathrm{g} / \mathrm{mL}$ cytochalasin B. The oocyte-cell complexes were fused in $0.28 \mathrm{M}$ mannitol solution containing $0.05 \mathrm{mM} \mathrm{Ca}^{2+}, 0.1 \mathrm{mM} \mathrm{Mg}^{2+}$, and $0.3 \mathrm{mg} / \mathrm{mL}$ BSA. Cell fusion was induced with two direct pulses of $2.0 \mathrm{kV} / \mathrm{cm}$ for $20 \mu \mathrm{s}$ each, using a BTX Electrocell Manipulator 2001 (BTX, San Diego, CA, USA). Fusion rates were determined 30 to $60 \mathrm{~min}$ after electrofusion, and successfully reconstructed oocytes were incubated in $\mathrm{HSOF}+10 \%(\mathrm{v} / \mathrm{v}) \mathrm{FBS}$ at $38.5^{\circ} \mathrm{C}$ under a humidified atmosphere of $5 \% \mathrm{CO}_{2}$ in air until activation.

Reconstructed oocytes were chemically activated $30 \mathrm{~h}$ post-maturation, using $5 \mu \mathrm{M}$ ionomycin for $5 \mathrm{~min}$ in HEPES-buffered TCM-199 supplemented with 10\% (v/v) FBS, followed by incubation in SOF supplemented with $20 \mathrm{mM}$ strontium chloride $\left(\mathrm{SrCl}_{2} \cdot 6 \mathrm{H}_{2} \mathrm{O}\right.$; Mallinckrodt, Hazelwood, MO, USA) and $10 \mu \mathrm{g} / \mathrm{mL}$ cytochalasin B for $6 \mathrm{~h}$ at $38.5^{\circ} \mathrm{C}$ under a humidified atmosphere of $5 \% \mathrm{CO}_{2}$ in air (Yamazaki et al., 2005).

\section{Parthenogenetic embryos}

To obtain parthenogenetic blastocysts, oocytes matured for $24 \mathrm{~h}$ were denuded, selected for the first polar body presence, and kept in maturation medium until activation. At $30 \mathrm{~h}$ postmaturation, oocytes were activated with ionomycin followed by incubation in strontium supplemented with cytochalasin $\mathrm{B}$, as described previously for activation of reconstructed oocytes.

\section{Embryo in vitro culture and embryo transfer}

Embryo culture was performed in $100-\mu \mathrm{L}$ microdrops of modified SOF (Vajta et al., 1999) containing $5 \mathrm{mg} / \mathrm{mL}$ fatty acid-free BSA and $2.5 \%$ (v/v) FBS, overlaid with mineral oil. Groups of 10 to 20 embryos were cultured together in each microdrop at $38.5^{\circ} \mathrm{C}$ under a humidified atmosphere of $5 \% \mathrm{CO}_{2}$ in air for 7 days, until the blastocyst stage.

Crossbreed $B$. indicus x $B$. taurus cows were synchronized with $150 \mu \mathrm{g}$ D-cloprostenol, and females showing estrus received 7 blastocysts produced by IVF, SCNT or parthenogenetic activation. On day 30 of gestation, the presence of the conceptus was determined by per rectum ultrasound examination. Surrogate cows with positive diagnosis were slaughtered between days 33 and 36 of pregnancy.

\section{Recovery of conceptus and embryonic membranes}

Immediately after slaughter of pregnant cows, the reproductive tract was removed, placed on ice, and transported to the laboratory. The uterine horns were dissected 
by cutting along the major curvature, exposing the conceptus and embryonic membranes. The entire embryos and fragments of chorio-allantoic membranes were collected, frozen in liquid nitrogen, and stored at $-80^{\circ} \mathrm{C}$. A total of eleven embryos were recovered, two in the SCNT group and three in each of the in vivo, IVF, and parthenogenetic groups.

\section{Analysis of gene expression}

RNA extraction of in vivo-, IVF-, SCNT-, and parthenogenetic-derived 33- to 36day embryos and chorio-allantoic membranes was performed using the TRIzol reagent (Invitrogen, Carlsbad, CA, USA), following manufacturer instructions.

For reverse transcription, $1 \mu \mathrm{g}$ total RNA was incubated for $5 \mathrm{~min}$ at $70^{\circ} \mathrm{C}$ with $6.75 \mu \mathrm{M}$ oligo-dT $\left(\mathrm{pd}(\mathrm{T})_{12-18}\right.$; Amersham Biosciences, Piscataway, NJ, USA), and then immediately cooled at $4{ }^{\circ} \mathrm{C}$ before the addition of $50 \mathrm{U}$ reverse transcriptase enzyme (ImProm-II ${ }^{\mathrm{TM}}$ Reverse Trascriptase, Promega, Madison, WI, USA) and reagent mix: buffer - $250 \mathrm{mM}$ Tris, $375 \mathrm{mM} \mathrm{KCl}, 50 \mathrm{mM}$ DTT, $3 \mathrm{mM} \mathrm{MgCl}, 20.5 \mathrm{mM}$ of each dNTP (Invitrogen), and $2 \mathrm{U} / \mu \mathrm{L}$ of RNase inhibitor (Amersham Biosciences) in a final volume of $20 \mu \mathrm{L}$. Samples were heated to $42^{\circ} \mathrm{C}$ for $1 \mathrm{~h}$, incubated at $70^{\circ} \mathrm{C}$ for $15 \mathrm{~min}$, and frozen at $-20^{\circ} \mathrm{C}$ until use.

Amplifications were performed in a real time polymerase chain reaction (PCR) thermocycler (Applied Biosystems 7500 Real Time PCR System, Applied Biosystems, Foster City, CA, USA) using Power SYBR Green ${ }^{\circledR}$ PCR Master Mix (Applied Biosystems), $0.06 \mu \mathrm{M}, 0.20 \mu \mathrm{M}$, and $0.50 \mu \mathrm{M}$ of each pair of primer for glyceraldehyde-3phosphate dehydrogenase $(G A P D H), I G F 2$, and $I G F 2 R$, respectively, in a $20-\mu \mathrm{L}$ reaction. The reaction was initiated with incubation at $50^{\circ} \mathrm{C}$ for $2 \mathrm{~min}$, followed by denaturation at $95^{\circ} \mathrm{C}$ for $10 \mathrm{~min}$, and 45 cycles at $95^{\circ} \mathrm{C}$ for $30 \mathrm{~s}$ and $60^{\circ} \mathrm{C}$ for $1 \mathrm{~min}$. Sequences of primers for imprinted and housekeeping $(G A P D H)$ genes are shown in Table 1.

\begin{tabular}{|c|c|c|}
\hline Gene & Sequence $\left(5^{\prime} \rightarrow 3^{\prime}\right)$ & GenBank \\
\hline$I G F 2$ & $\begin{array}{l}\text { CTTCAGCCGACCATCCAGCCGCATAAAC } \\
\text { TCAGCGGACGGTGACTCTTGGCCTCTCT }\end{array}$ & X53553 \\
\hline$I G F 2 R$ & $\begin{array}{l}\text { CGCCTACAGCGAGAAGGGGTTAGTC } \\
\text { AGAAAAGCGTGCACGTGCGCTTGTC }\end{array}$ & JO3527 \\
\hline GAPDH & $\begin{array}{l}\text { GCGTGAACCACGAGAAGTATAA } \\
\text { CCCTCCACGATGCCAAAGT }\end{array}$ & AB098979 \\
\hline
\end{tabular}

The PCR efficiency was estimated for GAPDH and imprinted genes in each sample using a method and software published previously (Ramakers et al., 2003) applying default parameters (number of points between 4 and 6 and best correlation coefficient). For each pair of primers, the fluorescence threshold line was fixed at the average of the lower and higher fluorescence values used by the software to estimate PCR efficiency. 
Fold differences in amount of $G A P D H$ or target genes mRNA were calculated by the equation: fold change $=[1+(\text { average PCR efficiency) })]^{\text {average } \mathrm{Ct} \text { test - average Ct reference }}($ Livak and Schmittgen, 2001).

To measure the differences, we used the pair-wise fixed reallocation randomization test in the Relative Expression Software Tool (REST; Pfaffl et al., 2002). The hypothesis of no difference between groups was the null one $\left(\mathrm{H}_{0}\right)$ and the differences were considered to be statistically significant when the probability of the alternative hypothesis $\left[\mathrm{P}_{(\mathrm{H} 1)}\right]$ was less than 0.05 .

\section{RESULTS}

The comparisons of imprinted gene expression in 33- to 36-day embryos produced in vivo or in vitro demonstrated a lower expression $(\mathrm{P}<0.05)$ of IGF2 in SCNT $(0.19)$ and parthenogenetic-derived samples (0.02) when compared to in vivo and IVF (2.01; Figure 1). However, no differences were observerd $(\mathrm{P}>0.05)$ among groups in IGF2R gene expression (Figure 1).

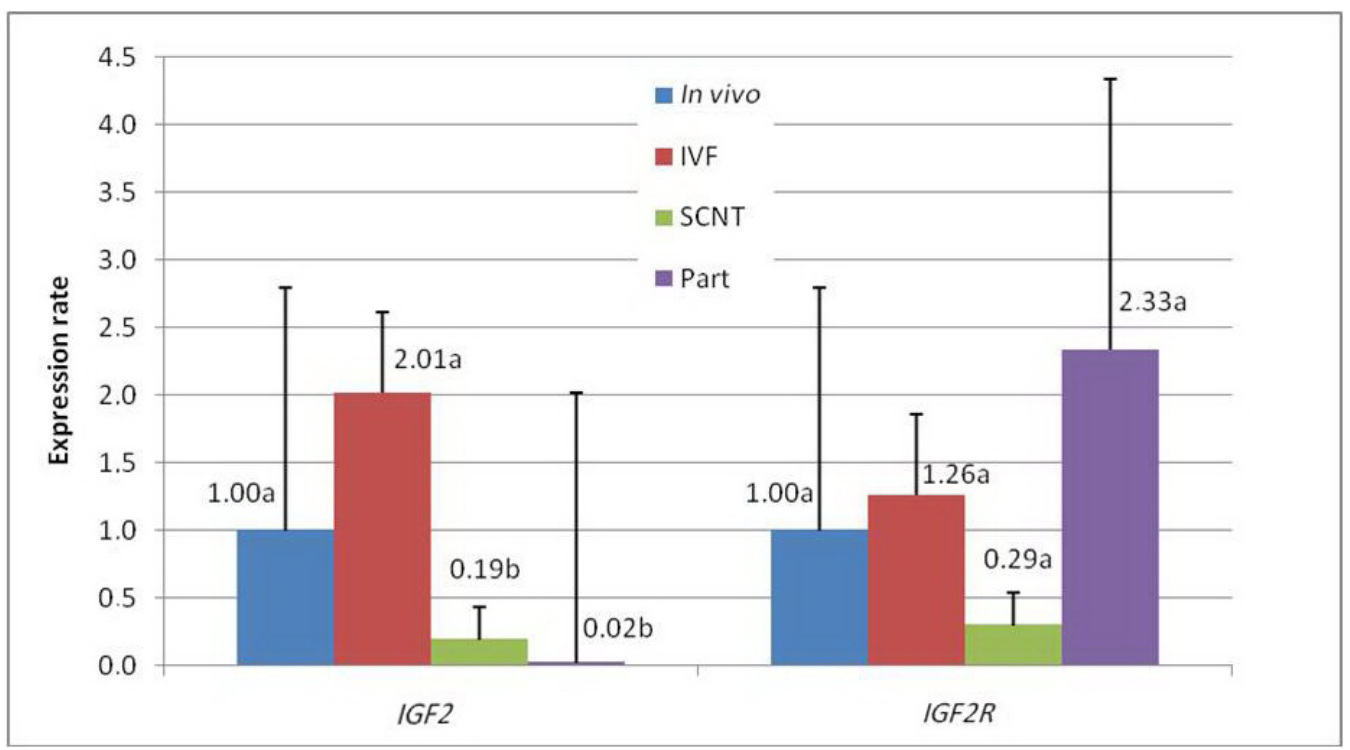

Figure 1. Rate of expression of $I G F 2$ and $I G F 2 R$ in embryos derived from in vivo- or in vitro-produced blastocysts [in vitro fertilization (IVF), somatic cell nuclear transfer (SCNT), and parthenogenetic (Part) groups]. Values followed by different letters differ significantly $(\mathrm{P}<0.05)$. Reference group $=$ in vivo.

The analysis of chorio-allantoic membranes of the bovine conceptus revealed a baseline expression pattern $(\mathrm{P}<0.05)$ in the $I G F 2$ gene in parthenogenetic-derived samples $(0.001)$ when compared to in vivo, IVF (3.13), and SCNT (0.98). A lower expression was observed $(\mathrm{P}<0.05)$ in $I G F 2 R$ gene in SCNT-derived samples $(0.25)$ when compared to the IVF group (1.21; Figure 2). 


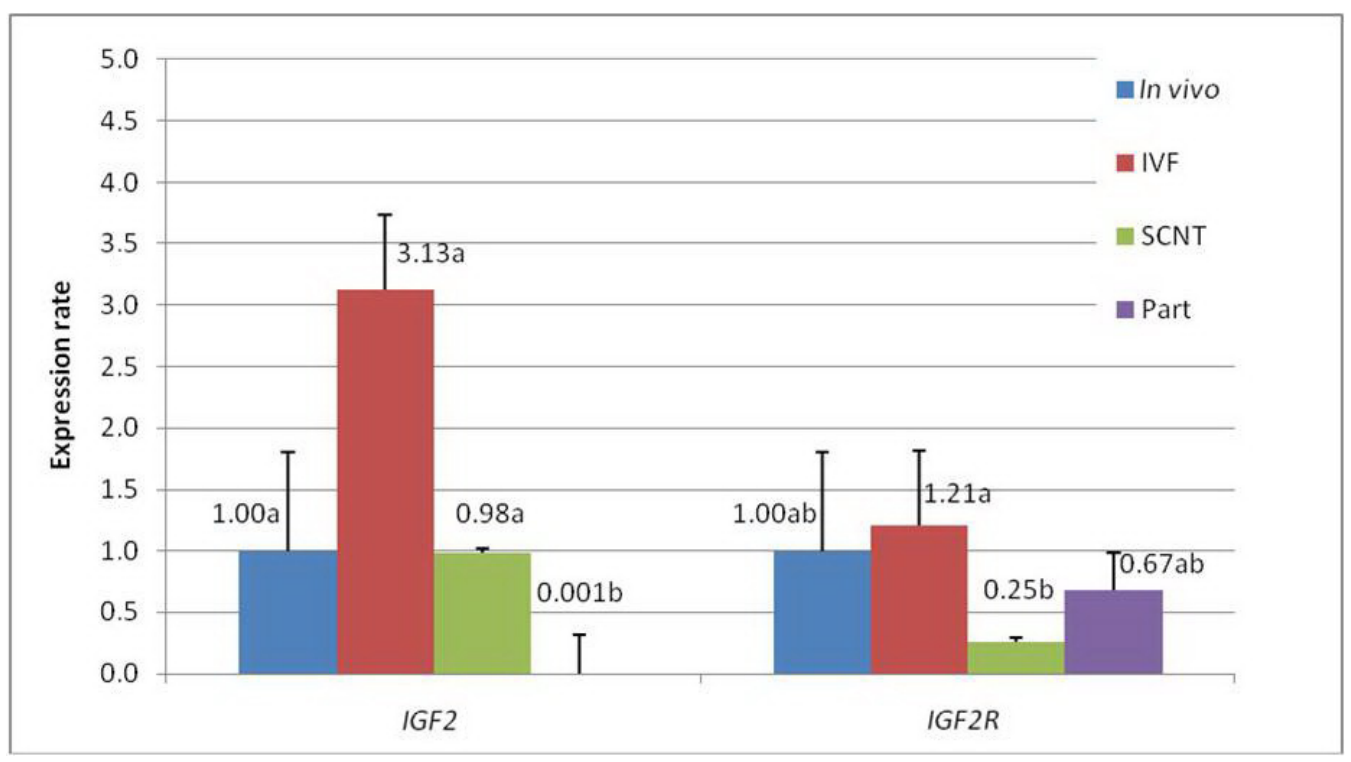

Figure 2. Rate of expression of $I G F 2$ and $I G F 2 R$ in chorio-allantoic membranes of conceptus derived from in vivo- or in vitro-produced blastocysts [in vitro fertilization (IVF), somatic cell nuclear transfer (SCNT), and parthenogenetic (Part) groups]. Values followed by different letters differ significantly $(\mathrm{P}<0.05)$. Reference group $=$ in vivo .

\section{DISCUSSION}

About 112 genes or non-coding RNAs are known to be imprinted in humans and mice, and some of these are conserved in ruminants (Reik and Walter, 2001; Young et al., 2003; Morison et al., 2005). Dozens of them are involved in fetal growth and development, and are particularly important to normal placenta development and nutrient transport from placenta to fetus, especially amino acids and glucose (Tilghman, 1999; Constância et al., 2002). In general, maternally derived imprinted genes reduce growth while paternally derived imprinted genes promote growth, and this occurs both in fetal and placental tissues.

The maintenance of differential patterns of methylation, at the differentially methylated regions (DMR) of alleles, is determinant to monoallelic expression of imprinted genes. Therefore, the loss of DNA methylation at DMR leads to $I G F 2$ and $I G F 2 R$ being normally expressed by paternal and maternal alleles, respectively, to become silenced, while $H 19$, normally expressed from the maternal allele, shows biallelic expression (Li et al., 1993).

The $I G F 2$ gene codes for a growth factor involved in fetal and placental development. In humans, the IGF2 gene is related to the Silver-Russell syndrome (SRS), characterized by the lack of methylation at the IGF2-H19 imprinted control region (ICR), lower $I G F 2$ expression, and biallelic expression of $H 19$, with intrauterine and postnatal growth retardation (Bliek et al., 2006). Oppositely, the overexpression of $I G F 2$ in humans causes the Beckwith-Wiedemann syndrome (BWS), characterized by biallelic methylation of IGF2-H19 ICR, lack of $H 19$ expression, and biallelic expression of IGF2. The individual affected by BWS shows pre- and postnatal overgrowth, organomegaly and neonatal hypoglycemia (Delaval et al., 2006). Similarly, the 
overexpression of $\operatorname{Ig} 22$ in mice promotes fetal overgrowth (Eggenschwiler et al., 1997), while underexpression of $\operatorname{Ig} f 2$ was associated with a deficit in growth (DeChiara et al., 1990).

In cattle, the use of IVF and cloning raised the incidence of offspring with symptoms that resemble BWS or SRS, such as the large offspring syndrome (LOS) or the retardation of development, commonly seen in animals produced by reproductive biotechnologies (DeBaun et al., 2003; Mann et al., 2003; Young et al., 2003). Overexpression of IGF2 has been described in cardiac and hepatic tissues of cloned calves (Li et al., 2007) with neonatal death, as well as in renal tissues of cloned mice (Humpherys et al., 2002). Abnormal expression of Igf2 was also described in the fetus and placenta of cloned mice (Ogawa et al., 2003) or in placentas of cloned calves after birth (Yamazaki W, Perecin F, Méo SC, Ferreira CR, et al., unpublished data) with lower expression rates in both cases.

In our results, similar expression of IGF2 between IVF and in vivo contrasted with decreased expression in SCNT group in embryonic tissues. In chorio-allantoic membranes, similar expression of IGF2 between in vivo, SCNT, and IVF groups was observed. The almost complete absence of $I G F 2$ transcripts in embryonic tissues as well as in the chorio-allantois derived from parthenogenesis supported its maternal imprinted status in ruminants. The placental phenotype and its capacity to transfer substances from the mother to the fetus depend on the interplay between placental and fetal $I G F 2$, with direct influence on fetus growth (Coan et al., 2008). The ratios between placental and embryonic IGF2 expression rates were 1.0, 1.5 and 5.1 for in vivo, IVF and SCNT, respectively, indicating a pronounced imbalance of $I G F 2$ in cloned-derived tissues.

The $I G F 2 R$ gene, paternally imprinted, also plays an important role as negative effector in fetal growth since it promotes $I G F 2$ arrest into lysosomes followed by degradation (Lau et al., 1994; Ludwig et al., 1996). In sheep, parthenogenetic embryos express low levels of $I G F 2$ and high levels of $I G F 2 R$ and $H 19$, and have retarded growth when compared to control embryos (Feil et al., 1998; Hagemann et al., 1998; Young et al., 2003). Conversely, the absence of $I G F 2 R$ expression in ovine embryos submitted to in vitro culture is associated with LOS (Young et al., 2001), demonstrating that the culture conditions affect the imprinting status of $I G F 2 R$.

We observed lower $I G F 2 R$ expression in chorio-allantoic membranes derived from embryos produced by SCNT. Long and Cai (2007) examining cloned bovine fetuses that suffered perinatal death found aberrant patterns of DNA methylation at IGF2R ICR, as did Young et al. (2003) who observed loss of methylation in IGF2R DMR of cloned sheep. Similar observations in cloned murine fetuses were described by Ogawa et al. (2003). Reduced expression of $I G F 2 R$ was described in cardiac, hepatic, and renal tissue of cloned calves with neonatal death (Li et al., 2007), contrasting with the results described by Yang et al. (2005), in which no alteration in $I G F 2 R$ expression was found in dead neonatal cloned calves. However, despite that hypomethylation in $I G F 2 R$ DMR has been frequently reported, alterations in $I G F 2 R$ expression in the placenta of cloned animals that developed to term have never been found.

Given that $I G F 2 R$ acts as a clearance receptor for $I G F 2$, the balance between the two genes is important to regulate the effects of $I G F 2$. Young et al. (2001) showed reduced expression of $I G F 2 R$ in cloned fetuses with overgrowth, assuring that the lack of $I G F 2$ clearance may give rise to LOS. In our results, although some variation was seen in the ratio IGF2/IGF2R in both IVF and SCNT embryos and in IVF chorio-allantois, a striking imbalance was observed in SCNT chorio-allantois due to lower expression of $I G F 2 R$. Functional and morphological deficiencies in the placenta are commonly observed in gestations of cloned animals (Farin et 
al., 2006; Miglino et al., 2007). Frequently, these alterations include placental overgrowth that occurs before fetal overgrowth (Constant et al., 2006), suggesting that some of the problems observed in cloned animals have their origin in the placenta and not in the conceptus.

Another gene that can affect $I G F 2$ post-transcriptionally is the $H 19$ gene (Runge et al., 2000). Located at the flanking position of H19-IGF2 ICR, it gives rise to a non-coding RNA that acts through an unclear mechanism regulating the amount of the IGF-II protein. We also assessed the expression rates of $H 19$ in the same tissues as for IGF2 and IGF2R, but no significant differences among groups were found (data not shown).

After fertilization, the distinct epigenetic marks between alleles are already established and are maintained throughout development. Therefore, it is unclear when the alterations observed in imprinted genes occur. Although a possible origin in the gametes cannot be discarded, several observations indicate that these failures frequently occur after fertilization, i.e., the presence of mosaicism in DNA methylation patterns is observed in monozygotic twins in which only one has imprinting abnormalities (Bailey et al., 1995). The epigenetic control of imprinted genes through DNA methylation provides a linking mechanism between environmental stimulus and the epigenotypes. Thus, together with the fact that animals produced by nuclear transfer are more prone to show signs associated with imprinted gene disruptions, the role of in vitro culture conditions or gamete manipulations in the ethiogenesis of these problems must be considered.

The significant alterations in the level of transcripts from imprinted genes in SCNTderived embryos and placentas indicate that abnormal expression of imprinted genes is one of the causes for the low efficiency of cattle cloning. The alterations observed in embryos and placentas produced by SCNT are suggestive of modifications of DNA methylation at the ICRs of $I G F 2$ and $I G F 2 R$.

\section{ACKNOWLEDGMENTS}

Research supported by the Foundation for the Support of Research of the State of São Paulo (FAPESP), Brazil.

\section{REFERENCES}

Bailey W, Popovich B and Jones KL (1995). Monozygotic twins discordant for the Russell-Silver syndrome. Am. J. Med. Genet. 58: 101-105.

Bliek J, Terhal P, van den Bogaard MJ, Maas S, et al. (2006). Hypomethylation of the H19 gene causes not only SilverRussell syndrome (SRS) but also isolated asymmetry or an SRS-like phenotype. Am. J. Hum. Genet. 78: 604-614.

Coan PM, Fowden AL, Constancia M, Ferguson-Smith AC, et al. (2008). Disproportional effects of Igf2 knockout on placental morphology and diffusional exchange characteristics in the mouse. J. Physiol. 586: 5023-5032.

Constância M, Hemberger M, Hughes J, Dean W, et al. (2002). Placental-specific IGF-II is a major modulator of placental and fetal growth. Nature 417: 945-948.

Constant F, Guillomot M, Heyman Y, Vignon X, et al. (2006). Large offspring or large placenta syndrome? Morphometric analysis of late gestation bovine placentomes from somatic nuclear transfer pregnancies complicated by hydrallantois. Biol. Reprod. 75: 122-130.

DeBaun MR, Niemitz EL and Feinberg AP (2003). Association of in vitro fertilization with Beckwith-Wiedemann syndrome and epigenetic alterations of LIT1 and H19. Am. J. Hum. Genet. 72: 156-160.

DeChiara TM, Efstratiadis A and Robertson EJ (1990). A growth-deficiency phenotype in heterozygous mice carrying an insulin-like growth factor II gene disrupted by targeting. Nature 345: 78-80.

Delaval K, Wagschal A and Feil R (2006). Epigenetic deregulation of imprinting in congenital diseases of aberrant growth. 
Bioessays 28: 453-459.

Eggenschwiler J, Ludwig T, Fisher P, Leighton PA, et al. (1997). Mouse mutant embryos overexpressing IGF-II exhibit phenotypic features of the Beckwith-Wiedemann and Simpson-Golabi-Behmel syndromes. Genes Dev. 11: 3128-3142.

Farin PW, Piedrahita JA and Farin CE (2006). Errors in development of fetuses and placentas from in vitro-produced bovine embryos. Theriogenology 65: 178-191.

Feil R, Khosla S, Cappai P and Loi P (1998). Genomic imprinting in ruminants: allele-specific gene expression in parthenogenetic sheep. Mamm. Genome 9: 831-834.

Hagemann LJ, Peterson AJ, Weilert LL, Lee RS, et al. (1998). In vitro and early in vivo development of sheep gynogenones and putative androgenones. Mol. Reprod. Dev. 50: 154-162.

Holmes R and Soloway PD (2006). Regulation of imprinted DNA methylation. Cytogenet. Genome Res. 113: 122-129.

Humpherys D, Eggan K, Akutsu H, Friedman A, et al. (2002). Abnormal gene expression in cloned mice derived from embryonic stem cell and cumulus cell nuclei. Proc. Natl. Acad. Sci. U. S. A. 99: 12889-12894.

Lau MM, Stewart CE, Liu Z, Bhatt H, et al. (1994). Loss of the imprinted IGF2/cation-independent mannose 6-phosphate receptor results in fetal overgrowth and perinatal lethality. Genes Dev. 8: 2953-2963.

Li E, Beard C and Jaenisch R (1993). Role for DNA methylation in genomic imprinting. Nature 366: 362-365.

Li S, Li Y, Yu S, Du W, et al. (2007). Expression of insulin-like growth factors systems in cloned cattle dead within hours after birth. Mol. Reprod. Dev. 74: 397-402.

Livak KJ and Schmittgen TD (2001). Analysis of relative gene expression data using real-time quantitative PCR and the 2(-Delta Delta C(T)) method. Methods 25: 402-408.

Long JE and Cai X (2007). Igf-2r expression regulated by epigenetic modification and the locus of gene imprinting disrupted in cloned cattle. Gene 388: 125-134.

Ludwig T, Eggenschwiler J, Fisher P, D’Ercole AJ, et al. (1996). Mouse mutants lacking the type 2 IGF receptor (IGF2R) are rescued from perinatal lethality in Igf2 and Igf1r null backgrounds. Dev. Biol. 177: 517-535.

Mann MR, Chung YG, Nolen LD, Verona RI, et al. (2003). Disruption of imprinted gene methylation and expression in cloned preimplantation stage mouse embryos. Biol. Reprod. 69: 902-914.

Miglino MA, Pereira FT, Visintin JA, Garcia JM, et al. (2007). Placentation in cloned cattle: structure and microvascular architecture. Theriogenology 68: 604-617.

Morison IM, Ramsay JP and Spencer HG (2005). A census of mammalian imprinting. Trends Genet. 21: 457-465.

Ogawa H, Ono Y, Shimozawa N, Sotomaru Y, et al. (2003). Disruption of imprinting in cloned mouse fetuses from embryonic stem cells. Reproduction 126: 549-557.

Pfaffl MW, Horgan GW and Dempfle L (2002). Relative expression software tool (REST) for group-wise comparison and statistical analysis of relative expression results in real-time PCR. Nucleic Acids Res. 30: e36.

Ramakers C, Ruijter JM, Deprez RH and Moorman AF (2003). Assumption-free analysis of quantitative real-time polymerase chain reaction (PCR) data. Neurosci. Lett. 339: 62-66.

Reik W and Walter J (2001). Genomic imprinting: parental influence on the genome. Nat. Rev. Genet. 2: 21-32.

Runge S, Nielsen FC, Nielsen J, Lykke-Andersen J, et al. (2000). H19 RNA binds four molecules of insulin-like growth factor II mRNA-binding protein. J. Biol. Chem. 275: 29562-29569.

Tilghman SM (1999). The sins of the fathers and mothers: genomic imprinting in mammalian development. Cell 96: 185-193.

Vajta G, Rindom N, Peura TT, Holm P, et al. (1999). The effect of media, serum and temperature on in vitro survival of bovine blastocysts after Open Pulled Straw (OPS) vitrification. Theriogenology 52: 939-948.

Wells DN, Misica PM and Tervit HR (1999). Production of cloned calves following nuclear transfer with cultured adult mural granulosa cells. Biol. Reprod. 60: 996-1005.

Yamazaki W, Ferreira CR, Meo SC, Leal CL, et al. (2005). Use of strontium in the activation of bovine oocytes reconstructed by somatic cell nuclear transfer. Zygote 13: 295-302.

Yang L, Chavatte-Palmer P, Kubota C, O'Neill M, et al. (2005). Expression of imprinted genes is aberrant in deceased newborn cloned calves and relatively normal in surviving adult clones. Mol. Reprod. Dev. 71: 431-438.

Young LE, Fernandes K, McEvoy TG, Butterwith SC, et al. (2001). Epigenetic change in IGF2R is associated with fetal overgrowth after sheep embryo culture. Nat. Genet. 27: 153-154.

Young LE, Schnieke AE, McCreath KJ, Wieckowski S, et al. (2003). Conservation of IGF2-H19 and IGF2R imprinting in sheep: effects of somatic cell nuclear transfer. Mech. Dev. 120: 1433-1442. 